\title{
Obituary
}

\section{Professor Erwin Meyer}

WIrH the death of Erwin Meyer on March 5 at Pontresina in Switzerland, international acoustics has lost its leading and most versatile worker. Born on July 21, 1899, at Königshütte, then part of Germany, Professor Meyer spent nearly half a century teaching and researching acoustics. Meyer studied mathematics and physics under Waitzmann and Lummer at the University of Breslau, where he gained his $\mathrm{PhD}$ in 1922 for work on the interaction of sound waves and resonating membranes. After spending two years as an assistant in Breslau, Meyer became a member of the scientific staff under Professor K. W. Wagner at the Postal Telegraph Communication Centre, Berlin, which was followed by his appointment in 1.928 as a lecturer at the Technical University, Berlin-Charlottenberg. From 1929 to 1947 he was head of the acoustical department of the HeinrichHertz Institute, Berlin-Charlottenberg, and in 1947 he was appointed full professor in physics at the University of Göttingen, and director of the Third
Physical Institute which he himself founded.

For his outstanding contributions in many varied fields of acoustics Meyer received numerous honours. As early as 1933 he received the Gauss-Weber medal for outstanding achievements in electrical communications and was also awarded a honorary degree in engineering from the Technical University of Berlin. Subsequently in 1950 he became a member of the Academy of Sciences at Göttingen, which was followed in 1964 by the bestowal of the Wallace Clement Sabine Award of the Acoustical Society of America for his internationally recognized contributions to all aspects of architectural acoustics. During the course of his career Meyer designed numerous sound studios, theatres, opera houses, concert halls and multipurpose auditoria, and amongst the latter should be mentioned the new Festival Hall near Frankfürt, which is notable for having one of the largest electroacoustical systems for artificial reverberation, and has been praised by such eminent musicians as Yehudi Menuhin.
When the British Acoustical Society instituted its Rayleigh Medal Award in 1969 there was no hesitation in naming Erwin Meyer as its first recipient. For his address he chose the subject of wave absorbers, in which he introduced his oft-quoted analogy between electromagnetic microwaves and sound waves. These two disciplines have formed the basis of the teaching and research in the Dritter Physikalisches Institut. Before the Second World War Meyer gave some excellent lectures in experimental electroacoustics at the University of London, and after the war a strong bond of scientific cooperation between the Germans and the British, particularly in underwater acoustics, grew up, and Meyer was in receipt of British supporting funds for over twenty years.

Professor Meyer was a co-author of several acoustical books and at the time of his death he was working actively on the completion of the final volume of a set of four texts. $\mathrm{He}$ was cofounder and editor of Akustische Zeitschrift, but after the war he leaned towards an international journal and played a vital role in the establishment
(Continued from $p .145)$

74 Allison, A. C., Brit. Med. J., 1, 290 (1954).

75 Ceppellini, R., Att. 111, AGI, Suppl. la Ricerca Scientifica, 3 (1957).

76 Workman, P. L., Blumberg, B. S., and Cooper, A. J., Amer. J. Hum. Genet. 15, $429(1963)$

77 Wright, S., Evolution, 18, 609 (1965)

78 Fisher, R. A., The Genetical Theory of Natural Selection, second ed. (Dover, New York, 1958).

79 Fellous, M., and Dausset, J., Nature, 225, 191 (1970).

80 Piazza, A., Mattiuz, P. L., and Ceppellini, R., Haematologica, 54, 701 (1969).

81 McDevitt, H. O., Bechtol, K., Grumet, F. C., Mitchell, G. F., and Wegmann, T. G., Progress in Immunology (Proc. First Intern. Cong. Immunol.), 495 (Academic Press, 1971)

82 Transplant. Rev., 5 (1970)

83 Natvig, J. B., Kunkel, H. G., and Litwin, S. D., Cold Spring Harbor Symp. Quant. Biol., 32, 173 (1967).

84 Herzenberg, L. A., McDevitt, H. O., and Herzenberg, L. A. Ann. Rev. Genet., 2, 209 (1968).

85 Amos, B., Cabrera, G., Bias, W. B., MacQueen, J. M., Lanaster, S. L., Southworth, J. G., and Ward, F. E., Histocompatibility Testing 1970, 259 (Munksgaard, Copenhagen, 1970).

${ }^{86}$ Mole, L. E., Jackson, S. A., Porter, R. R., and Wilkinson, J. M., Biochem. J., 124, 301 (1971).

87 Mage, R. G., Young-Cooper, G. O., and Alexander, C., Nature, 230, 63 (1971).

88 Bach, F., and Amos, D. B., Science, 156, 1506 (1967).

89 Shellekens, P. Th. A., Vriesendorp, B., Eijsvogel, V. P., van Leeuwen, A., van Rood, J. J., Miggiano, V., and Ceppellini, R., Clin. Exp. Immunol., 6, 241 (1970).

90 Plate, J. M., Ward, F. E., and Amos, D. B., Histocompatibility Testing 1970, 531 (Munksgaard, Copenhagen, 1970).

$9 \mathrm{t}$ Yunis, E. J., and Amos, D. B., Proc. US Nat. Acad. Sci., 68, 3031 (1971).

92 Ceppellini, R., Progress in Immunology (Proc. First Intern. Congr. Immunol.), 973 (Academic Press, 1971).
${ }^{3}$ Eijsvogel, V. P., Shellekens, P. Th. A., Vriesendorp, B., van Leeuwen, A., Koch, C., and van Rood, J. J., Histocompatibility Testing 1970, 523 (Munksgaard, Copenhagen, 1970).

94 Koch, C. T., Eijsvoogel, V. P., Fredericks, E., and van Rood, J. J., Lancet, ii, 1334 (1971).

95 Ceprellini, R., in Human Transplantation (edit. by Rapaport, R. T., and Dausset, J.), 21 (Grune and Stratton, New York, 1968).

96 Rychlikova, M., Demant, P., and Ivanyi, P., Nature, 230, 271 (1971).

97 Dupont, B., Nielsen, L. S., and Svejgaard, A., Lancet, ii, 1336 (1971).

${ }^{98}$ Lebrun, A., Sasportes, M., Lebrun, D., and Dausset, J., $C R$ Acad. Sci., 273, 2130 (1971).

99 Moscona, A., Proc. US Nat. Acad. Sci., 43, 184 (1957).

100 Boyse, E. A., and Old, L. J., Ann. Rev. Genet., 3, 269 (1969).

101 Burnet, F. M., Nature, 232, 230 (1971).

102. Jerne, N. K., Europ. J. Immunol., 1, 1 (1971).

103 Itakura, K., Hutton, J. J., Boyse, E. A., and Old, L. J., Nature, 230, 126 (1971)

104 Schellekens, P. Th. A., and Eijsvoogel, V. P., Clin. Exp. Immunol., 7, $229(1970)$.

105 Dausset, J., Colombani, J., Legrand, L., and Fellous, M., Histocompatibility Testing 1970, 53 (Munksgaard, Copenhagen, 1970).

106 Williams, G. M., Rolley, R. T., and Home, D. M., Surg. Forum, 19, 209 (1968).

107 Perkins, H. A., Douglas, K. S., Cockrum, K., and Kountz, S., Histocompatibility Testing 1970, 583 (Munksgaard, Copenhagen, 1970).

108 Dausset, J., Transplant. Proc., 3, 1139 (1971)

109 Hellström, K. E., and Hellström, I., Ann. Rev. Microbiol., 24, $373(1970)$

110 Hellström, I., Hellström, K. E., and Allison, A. C., Nature, 230, 49 (1971).

111 Wegmann, T. Hellström, I., and Hellström, K. E., Proc. US Nat. Acad. Sci., 68, 1644 (1971).

112 Ceppellini, R., Bonnard, G. D., Coppo, F., Miggiano, V. C., Pospisil, M., Curtoni, E. S., and Pellegrino, M., Transplant. Proc., 3, 63 (1971). 
of Acustica, of which he was a coeditor until his death.

Erwin Meyer's enthusiasm for his subject inspired the band of young research workers who gathered around him at Göttingen, and the achievements at the University and the Institute bear testimony to the fine spirit of cooperation and goodwill which existed between teacher and students. His genial nature and humour won him many friends in different lands, and he will be greatly missed both for his excellence as a scientist and as a very human individual.

\section{Announcements}

\section{International Meetings}

May 29-June 2, Power from Radioisotopes Madrid (OECD, Château de la Muette, 2 rue André Pascal, Paris 16, France).

June 1-2, Influence of Amino-Acid Supply on Polynucleotide and Protein Metabolism, Aberdeen (Executive Secretary, The Biochemical Society, 7 Warwick Court, London WC1R 5DP).

June 1-2, Recent Developments in Vertebrate Smooth Muscle Physiology, London (Executive Secretary, The Royal Society, 6 Carlton House Terrace, London SWIY 5AG).

June 12-17, Health Physics Society Annual Meeting, Las Vegas (John S. Coogan, Environmental Protection Agency, Western Environmental Research Laboratory, PO Box 15027, Las Vegas, Nevada 89114, USA).

June 12-September 1, Gordon Research Conferences, New Hampshire (Alexander M. Cruickshank, Gordon Research Conferences, Pastore Chemical Laboratory, University of Rhode Island, Kingston, Rhode Island 02881 USA).
June 13-16, Fluidics, Uppsala (H. S. Stephens, British Hydromechanics Research Association, Cranfield, Bedford).

June 14-16, Metabolism and Membrane Permeability of Erythrocytes, Thrombocytes and Leucocytes, Vienna (Dr K. Moser, c/o Wiener Medizinische Akademie, Alserstrasse 4, 1090 Vienna, Austria).

June 18-23, Clinical Chemistry, Copenhagen (Eighth International Congress on Clinical Chemistry, Rigshospitalet, Blegdamsvej 9, DK-2100 Copenhagen $\varnothing$, Denmark).

June 19-20; Moiré Fringe Technology, East Kilbride (Conference Organizer, Birniehill Institute, National Engineering Laboratory, East Kilbride, Glasgow).

\section{Reports and Publications}

not included in the Monthly Books Supplement

\section{Great Britain and Ireland}

The Young Student's Laboratory Guide. By L. A. Redman. Pp. 28. (Lytham St. Annes: Specrum Books Limited, 1972.) 12p net.

Mp. 19. (London: The Association of the British Pharmaccutical Industry, 162 Regent Street, 1972.) [242 Academic Year 1970-1971. Pp. 32. (Cond 4893.) Academic Year 1925
(London: HMSO, 1972.) 24p net. Parkinson's Disease: a Booklet for Patients and Their Families. By R. B. Godwin-Austen. Pp. 8 . (London: Parkinson's Disease Society of the UK,
36 Queens Road, SW19, 1971.)
Field Studies Council Annual Report 1970/1971. Pp. 44. (London: Field Studies Council, 1972.) [252 Royal Institute of Chemistry. Monographs for . Industrial Chemistry-Organic By D. M. Samuel. Second edition. Pp. v+142. (London: The Royal Institute of Chemistry, 1972.)
[252 Safeguarding the Environment. Pp. 28. (Birmingham: The University of Aston in Birmingham,

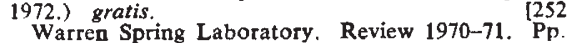
34. (Stevenage, Herts: Warren Spring Laboratory, 1972.) gratis.
National Museum of Wales. Sixty-fourth Annual National Museum of Wales. Sixty-fourth Annual
Report 1970-71. Pp. 141. (Cardiff: National Museum of Wales, 1971.) University of Edinburgh-Science Studies Unit. Second Report 1969-71. Pp. 16. (Edinburgh: The University, 1972.)

Philosophical Transactions of the Royal Society of London. A : Mathematical and Physical Sciences Vol. 272, No. 1219 (24 February, 1972): Rapid Force-Flux Transitions in Highly Porous Membranes. By P. Meares and K. R. Page. Pp. 1-46. (London
Industry and Technology in the Eighteenth Cen. tury : Britain and France. By Professor J. R. Harris. (An Inaugural Lecture delivered in the University of Birmingham on 27th May, 1971.) Pp. 18. 25p. Aristotle's Theory and Milton's Practice: Samson Agonistes. By Professor B. R. Rees. (An Inaugural Lecture delivered in the University of Birmingham on 4th November, 1971.) Pp. 25. 25p. (Birmingham: The University, 1972.)
Department of Trade and Industry. Research and Department of Trade and Industry. Research and
Development in Marine Technology. (St. Mary Cray, Orpington, Kent: Technology Report Centre, Department of Trade and Industry, 1972.) 11.50 . [23

\section{Other Countries}

A Science Policy for Canada: Report of the Senate Special Committee on Science Policy. Vol. 2: Targets and Strategies for the Seventies. Pp. \$ +329-608. (Ottawa: Information Canada, 1972.)
$\$ 232$ Bulletin of the American Museum of Natural History. Vol. 146, Article 2: A Revision of the American Groupers: Epinephelus and Allied Genera. By C. Lavett Smith. Pp. 67-242. \$6. Vol. 146, Article 3: Tertiary Fossil Species of the Rhinotermitidae (Isoptera), Phylogeny of Genera, and (Protozoa) and the Staphylinidae (Coleoptera). By York: American Museum of Natural History,
1971.) National Research Council of Canada. Annual Report on Support of University Research 1970-71 Pp. xiv + 467. (Ottawa: National Research Council
of Canada, i 972 .) \$2.50.
$[242$ Institut Royal Météorologique de Belgique.

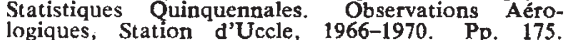
logiques, Station d'Uccle, $1966-1970$. Pp. 175. (Bruxelles: Institut Royal Météorologique de Council of Europe. Council for Cultural Cooperation. Continued Education: a Study of the Education of Young European School Leaver During Their Last Years at School and Early Years of Work. By E. W. Sudale. Pp. 117. (Strasbourg Council for Cultural Co-operation, Council of

Japan. National Institute of Radiation Breeding, Ministry of Agriculture and Forestry. Gamma Field Symposia No. 9: Mutagenesis in Relation to Ploid Level. Pp. 93. (Ohmiya-machi, Ibaraki-ken Peabody Peabody Museum of Natural History, Yale University. Bulletin No. 38: The Structure and RelaDipnorhynchus sussmilchi (Etheridge) LungfishDipnorhynchus sussmilchi (Etheridge). By Keith Stewart Thomson and K. S. W. Campbell. Pp. vi +109 . (New Haven, Con.: Peabody Museum Natural History, Yale University, 1971.) [252 Gouvernement du Quebec, Ministere de l'Agriculture et de la Colonisation. Recherches Agronomiques -Sommaire des Resultats, 1969/1970. (Le Conseil des Recherches Agricoles.) Pp. 156. (Quebec: 1970.)

FAO Forestry and Forest Products Studies, No. 17: Planning a Forest Inventory. By B. Husch Pp. $x+120$. (Rome: Food and Agriculture Organization of the United Nations; London: HMSO,
1971.) \$2.50; $£ 1$. Norsk Polarinstitutt. Arbok 1970. Pp. 302. (Oslo: Norsk Polarinstitutt, 1972.) [282 Unesco, Paris. Science for Development: an Essay on the Origin and Organization of Nationa Science Policies. By Jacques Spacy et al. Pp. 224.
(Paris: Unesco, 1971.) 18 francs; $£ 1.35 ; \$ 4.50$. [282

\section{HOW TO BUY NATURE}

Volumes start in January, March, May, July, September and November, but subscriptions may begin at any time.

The direct postal price per subscription is :

12 MONTHS * (52 issues per title)

\begin{tabular}{|c|c|c|}
\hline & $\begin{array}{c}\text { Surface mail } \\
\text { UK and } \\
\text { worldwide }\end{array}$ & $\begin{array}{l}\text { U.S.A. and } \\
\text { Canada }\end{array}$ \\
\hline Nature (Friday) & $£ 14$ & $\$ 48$ \\
\hline $\begin{array}{l}\text { Nature }+ \\
\text { Nature Physical Science }\end{array}$ & $\mathbf{2 4}$ & $\$ 83$ \\
\hline $\begin{array}{l}\text { Nature }+ \\
\text { Nature New Biology }\end{array}$ & $\varepsilon 24$ & $\$ 83$ \\
\hline All three editions & $\mathbf{2 9 . 5 0}$ & $\$ 108$ \\
\hline Annual index & $\mathbf{E}$ & $\$ \mathbf{3}$ \\
\hline
\end{tabular}

- Rates for shorter periods pro rata (minimum three months) (Charge for delivery by air mail on application)
Editorial and Publishing Offices of NATURE

MACMILLAN JOURNALS LIMITED

4 LITTLE ESSEX STREET, LONDON WC2R 3LF

Telephone Number: 01.836 6633. Telegrams: Phusis London WC2R 3LF Telex: 262024

711 NATIONAL PRESS BUILDING WASHINGTON DC 20004

Telephone Number: 202-737 2355. Telex: 64280

Subscription Department

MACMILLAN JOURNALS LIMITED

BRUNEL ROAD, BASINGSTOKE, HANTS

Telephone Number: Basingstoke 29242

American display advertisements

NATURE SCIENTIFIC PUBLICATIONS INC.

711 NATIONAL. PRESS BUILDING

WASHINGTON DC 20004

All other advertisements

T. G. SCOTT \& SON, LIMITED

1 CLEMENT'S INN, LONDON WC2A 2ED

Telephone 01-242 6264/01-405 4743

Telegrams: Textualist London WC2A 2ED

Registered as a newspaper at the Post Office

Copyright (C) Macmillan Journals Limited, May 191972 